\title{
The Effect of Using Reading Short Story in Students' Vocabulary Mastery at SMP HKBP Pajak Baru Belawan
}

\author{
Melly Stevani Aritonang ${ }^{1}$, Sondang Manik ${ }^{2}$ \\ Universitas HKBP Nommensen \\ sondang58manik@gmail.com
}

\begin{abstract}
This research was aimed to answer the question about the implementation of short story technique whether it can enrich the students' English vocabulary at Class VIII SMP HKBP PAJAK BARU BELAWAN or not, This is an experimental research. the writer tested the null hypothesis (Ho) which stated that the use of short story cannot enrich the students' English vocabulary at Class VIII,.The text that used for short story technique in this reseacrh was monologue text (a text that displays story teller) this research focused on narrative text (imaginative experiences) particularly, narrative text was related to the syllabus of the second semester for second grade of junior high school. After the Pretest, Treatment and Post test, there is a significant difference of mean score got both of experimental group (75.25) and the control group (72,75). $\mathrm{T}$-observe $>\mathrm{T}$ - table $(\mathrm{P}=0,05)$ df $(38)$, or 4,46 > 1,686 $(\mathrm{P}=$ $0,05)$. It means that alternative hypothesis (Ha) is accepted and null hypothesis (Ho) is rejected. Thus it can be conclude that by using Reading Short Story affects the students' vocabulary masterthat there is a significant effect of Reading Short Story in students' vocabulary mastery. In other words, alternative hypothesis (Ha) is accepted and null hypothesis (Ho) is rejected
\end{abstract}

Keywords: implementation of short story technique,reading short story

\section{Background of the Study.}

Vocabulary is one of English sub skills that must be taught to the students because vocabulary has an important role for all language skills. David Wilkins inThornburry (2002:13) states that without grammar very little can be conveyed,without vocabulary nothing can be conveyed. In other words, the first thing thathas to be mastered by language learners in learning language is vocabulary. In listening, students' vocabulary influences their understanding toward teacher'sspeech, class discussion, and other speeches. The words thatthey choose inspeaking affect how well they deliver a message. In reading, students' vocabularyaffects their ability to understand and comprehend a text. In addition, dealing withwriting, studentse vocabulary also influences how clear they convey their thoughtto the reader. In conclusion, vocabulary takes an important role in equippingstudents to be able to communicate in English.

Based on observations students at SMP HKBP PAJAK BARU BELAWAN faced some difficulties in mastering vocabulary and some problems in the field were identified. The first problem was related to the students. The Eight grade students of SMP HKBP PAJAK BARU BELAWAN did not have high motivation in learning vocabulary. They have difficulties in memorizing new words. Most of the students were passive during teaching and learning process. They did not have confidence in their ability and they were afraid of making mistake. So they tend to answer the questions if only the teacher called their name and forced them to answer. The second problem was related to the teacher. They did not know how to make the students interested in lesson. They applied a traditional method by looking for difficult words and finds the meaning 
in the dictionary and students supposed to memorize the words. It makes the students bored with the lesson and unmotivated to learn.The third problem was related to the materials. There were various English materials from other resources for supplementary materials, but the material used in teaching and learning activities were mostly taken fromthe course book and LKS (LembarKerjaSiswa).

Short story is one of many kinds of a books are students likely. Because, the students interesting to read Short story. Short story has many title arevarious with different themes. Usually, the students' of junior high school likes the story with a themes fairy tales or fables. In the Short story, the students can also find out many kinds of vocabulary. So, with these methods automatically the students can increase their vocabulary.

As a matter of fact, most students, especially, the second graders students of SMP HKBP PAJAK BARU Belawan found it difficult to guess the meanings of new words. The students felt difficult to understand the meanings of the unknown words appearing in sentences or text. When the teacher had the students guess the meanings of the underlined words of two sentences; there is a book on the table, and my father has booked a room in the hotel. They looked confused and did not know the appropriate meaning of those words. All of them said that the meaning of the word is buku. These all that caused the students' vocabulary achievement was very low

Based on this problem, the writer wanted to develop a good teaching and technique to taught vocabulary in enriching the students' vocabularymastery. Therefore, the writer choose the title "Improving students' vocabulary mastery through short story at SMP HKBP PAJAK BARU Belawan.'The writer tried to applied the Short Story to improve the students' vocabulary mastery and could reach of the Minimum Mastery Criterion (KKM) is 70.

In line with the observation that was conducted in SMP HKBP PAJAK BARU BELAWAN, the writer founded some problems related to the vocabulary teaching and learning process. The traditional method is usually used by looking for difficult words and finds the meaning in the dictionary and students supposed to memorize the words. They were lazy to memorize the unfamiliar words that they heard or reading the text. They had difficulties in understanding orcomprehending the meanings of unfamiliar words and memorizing new words. They had low vocabulary mastery. The class activities depend on textbook and LKS (LEMBAR KERJA SISWA).sed on the phenomena above, the writer tried to find the effective solution to improve the studentse vocabulary by using Short Story in the teaching learning process. Short Story is technique for the whole class that encourages students to study and review their vocabulary words. There are some reasons why I choose Short Story as the technique to improve their vocabulary mastery. First, Short Story can be used as one of interesting activities to review their vocabulary during the lesson. It can attract the students' attention and their involvement in the teaching and learning process. Second, students can learn how to work and cooperate as a group and also learn how to appreciate each other. Third, Short Story can create an enjoyable environment. Students can enjoy fun and joyful learning. Fourth, Short Story can help students revise their vocabulary and recalling something that happened in the learning process. It may help students remember the language connected with it.

In this research, the writer focussed on her study on word meaning. Short Story as a technique to improve the vocabulary mastery. The writerr has a reason why choose word meaning as aspects to focus in her research. The writer saw that most students in SMP HKBP PAJAK BARU Belawan have a lacks of vocabularies. In this case the meaning word of vocabulary is important to students comprehensively. So, if the students know what is meaning of vocabulary students can to easier to understanding the Short Story.

According to John (2000: 16), vocabulary is knowledge of knowing the meanings of words and therefore the purpose of a vocabulary test is to find out whether the learners can match each word with a synonym, a dictionary -tape definition, or an equivalent word in their own language. In learning vocabulary automatically they have to know the meaning of words themselves and can use it in sentences.

To make the discussion clearer, Harmer's opinion can be added. In his book, Harmer (2001: 16) says that there are some aspects that have to be discussed in vocabulary, namely: word meaning (synonym and antonym)and the grammar of words which comprises noun, verb, adjective and adverb, and this situation, the 
students needed a lot of time in understanding the text. The text that used for short story technique in this reseacrh was monologue text (a text that displays story teller) this research focused on narrative text (imaginative experiences) particularly, narrative text was related to the syllabus of the second semester for second grade of junior high school.

\section{The Hypothesis}

1. Hypothesis zero (Ho):there was not significantly of students' vocabulary mastery by using Short story technique at SMP HKBP PAJAK BARU BELAWAN.

2. Hypothesis alternative (Ha): there wassignificantly of students' vocabulary mastery by using Short story technique at SMP HKBP PAJAK BARU BELAWAN.

\section{The Nature of Vocabulary}

According to Ur (1996: 60) vocabulary can be defined roughly as theword teacher teaches in the foreign language. The term "words" here meansthat the new item of vocabulary maybe more than a single word, for example,father-in-law and police office, which are made up from two or more words but expressa single definition or idea. In other case there are also compound words called as multi-word idioms, for example call it a day.

Based on the definition above, it means that it can be concluded that vocabulary is a set/list of words of a particular language including single words, compound words and idioms that individual speakers of a language might use. This research took eight grade students of SMP HKBP BELAWAN as the subject and English vocabulary as an object. Vocabulary in this research is limited into a set/list of English words which is related to the theme that should be taught in term of describing people, tourism place, and historical place.

\section{Vocabulary Mastery}

The vocabulary mastery is not a spontaneous process which is easy to be done. The process of vocabulary mastery begins when someone is still an infant. Basically, the baby's first language comes from the mother tongue. They will master the vocabulary through the simple words by listening to the words which are uttered by someone else. It is known that English vocabulary learning cannot run successfully without English ability (English skills) because both of them are very important in English teaching and learning process.

\section{Vocabulary Assessment}

To make the discussion clearer, Harmer's opinion can be added. In his book, Harmer (2001: 16) says that there are some aspects that have to be discussed in vocabulary, namely: word meaning (synonym, antonym), extending word use such as idioms, word combination or collocation, and the grammar of words which comprises noun, verb, adjective, and adverb.

\section{Meaning}

The meaning can be classified according to the form they attach to. It can be classified into three forms: lexical meaning, morphological meaning, and syntactic meaning.

Lexical meaning is the meaning that attaches to words as word. For example, the meaning of a building for human habitation that attaches to house is lexical meaning. Morphological meaning is the meaning that attaches to morpheme. Morpheme is the smallest unit that carries information about meaning or function. And the meaning that attaches to the word arrangement in a sentence is the syntactic meaning. 
A word meaning can also be defined by its relationship to other words. One should also know the denotation and connotation of a word in order to know the negative or positive meanings that occur in the word.

\section{1) Synonym}

The term synonymy derives from Greek: syn- + -nymy. The two parts mean "same and name". Synonymy deals with sameness of meaning, more than one word having the same meaning, alternatively the same meaning being expressed by more than one word. In other words, synonym is words whose denotation is the same but has different connotation.

\section{2) Antonym}

Antonym is the opposite of meaning. It derives from Greek, "ant- and -onym", the two parts mean "opposite + name". Antonym deals with oppositeness of meaning. Antonyms are not differentiated for formality or dialect ortechnicality; antonyms occur within the same style, dialect, or register.

\section{Use}

According to Nation (2001:1), there are some ways to draw the attentions to the use of words by quickly showing the grammatical pattern the word fits into (countable/uncountable, transitive/intransitive, etc.), giving a few similar collocates, mentioning any restrictions on the use of the word (formal, informal,impolite, only used with children, etc.), and giving a well-known opposite or a well-known word describing the group or lexical set it fits into.

Based on the explanation above, it means that there are many ways attentions to the use of words especially in vocabulary. We can know the grammatical pattern the words into synonym, antonym or etc.

\section{Spelling}

According to Ur (1996: 60) there are some important points that should beconsidered when teaching vocabulary that is form (pronunciation and spelling). The learners have to know what a word sound is like (its pronunciation) and what it looks like (its spelling).

\section{Pronunciation}

According to Hewings (2004:3), pronunciation of a language is the main components of speech which combine together. These components range from the individual sounds that make up speech, to the way in pitch (the rise and fall of the voice is used to convey meaning).

According to Ur (1996: 60), there are some important points that should be considered when teaching vocabulary that is form (pronunciation and spelling). The learners have to know what a word sound is like (its pronunciation) and what it looks like (its spelling). These are fairly obvious characteristics and the words will be perceived by the learners when encountering the items for the first time. So it means that it can be inferred that learners should master the words of the language because language consists of words. It is in order to be able to use the language approximately. Having mastered a large number of words, they will be able to express their ideas in the language approximately.

\section{Narrative}

Narrative text is a story occurred in past time which its social function is to amuse or entertain the readers. It is written with certain characteristics and its language features. Narrative text can be imaginary or factual (fairy tales, fable, romances and adventure stories, and legends)

\section{Technique}

Technique is a detailed list of rules or a guideline for any (teaching) activity. It is based on the description of the steps, or a set of do's and don'ts, and is often associated with the method or strategy. According to brown(2001) technique (also commonly referred to by others terms): any of a wide variety of 
exercise, activities, or task used in language classroom for realizing lesson objective. Technique is the way a person in order to implement a method.

Based on the explanation above, that technique is including the way someone implements a method. Where this method is the way a teacher makes students succeed in achieving the learning goals that exist in the lesson or the assessment itself

\section{Short Story}

Short story deals with important elements that build the story itself. All of these elements take their own role to make the story sensible. They are theme, plot, setting, character and point of view (Al Alami, 2016). A short story refers to a work of fiction that is usually within prose in narrative format. It tends to be less complex than novels. Usually a short story focuses on only one incident, has a single plot, a single setting, a small number of characters, and over a short period of time.

It is clear that short stories are the most suitable literary genre to use in English teaching due to its shortness, as supported by Collie and Slater (1991) when they list four advantages of using short stories for language teachers. First, short stories are practical as their length is long enough to in one or two class sessions. Second, short stories are not complicated for students to work with on their own. Third, short stories have a variety of choice for different interests and tastes. Finally, short stories can be used with all levels (beginner to advance), all ages (young learners to adults) and all classes.

\section{The Relationship Vocabulary Mastery and Short Story}

According to Harmer $(2001 ; 4)$ vocabulary is one of the most obvious components of language and one of first things applied linguists turned their attention. Mastery English vocabulary is very important because, it will support the student's ability to master four laguage skill that are reading, speaking, listening, and writing, (Fauziati, 2002;115).

Short story deals with important elements that build the story itself. All of these elements take their own role to make the story sensible. They are theme, plot, setting, character and point of view (Al Alami, 2016). A short story refers to a work of fiction that is usuallywithin prose in narrative format. It tends to be less complex than novels. Usually a short story focuses on only one incident, has a single plot, a single setting, a small number of characters, and over a short periodof time.

There are many ways to test students' vocabulary. Like with multiple choices or essays. There is an assessment of vocabulary, grammar, relationship control and others. And in this section of the research technique this time we will use a Short story technique. Where is the type of speed reading technique by looking at specific parts to get information and understand the text to be able to make their own conclusion.

\section{Teaching Vocabulary Using Short Story}

According to Harmer $(2001 ; 4)$ vocabulary is one of the most obvious components of language and one of first things applied linguists turned their attention. Mastery English vocabulary is very important because, it will support the student's ability to master four laguage skill that are reading, speaking, listening, and writing, (Fauziati, 2002;115). Teaching is very personal activity, and it is not surprising that individual teacher being to teaching very different beliefs and assumption about what constitutes the effective teaching (Richard, 1994; 36).

In the process of learning vocabulary, not only the teachers that must be active, but also students must be more active in the learning process. Acording to McCharty $(1990 ; 121)$ active learners seem to make 
similarcontribution to those of the teachers in classroom interaction, they accept to organize new words in relation to words already known, they define and paraphrase words and try using words in example.

According to Scrivener $(1994 ; 80)$ a simple vocabulary lesson at beginner level might involve the teacher using techniques such as to introduce the learners to a short list of new words if the words are related to each other in some way. The teaching of new vocabulary would probably be followed by a practice activity in which the learners could find ways to use the words that they had just met or revised.

\section{Research Design}

The design of this study was experimental quantitative research. There were two kinds of variablesuch as: independent and dependent variable. Independent variable was by Short story technique while dependent variables were the students' vocabulary skill. In this case, the writer was investegated whether the independent variable affects the dependent one or not. Furthermore, in conducting the experimental research, there was two different groups; that was experimental group that will be received the treatment by applying Short story Technique and control group which was be treat without special treatment. Then both of them will be given pre-test and post-test with the same item.

The design of the study is figured out as the followings:

Table 1 The Design of the Study

\begin{tabular}{|c|c|c|c|}
\hline Group & Pre-Test & Treatment & Post-Test \\
\hline Control & $\sqrt{ }$ & $\begin{array}{l}\text { Without Using Short } \\
\text { story Technique }\end{array}$ & $\sqrt{ }$ \\
\hline Experimental & $\sqrt{ }$ & $\begin{array}{l}\text { Using Short story } \\
\text { Technique }\end{array}$ & $\sqrt{ }$ \\
\hline
\end{tabular}

Table 2 Table of Specification in Vocabulary Synonym and Antonym

\begin{tabular}{ccccc}
\hline Content & $\begin{array}{c}\text { Kinds of Word } \\
\text { Meaning }\end{array}$ & Content & Test Item & Score \\
\hline \multirow{4}{*}{ Word } & Synonym & Adjective & 5 & 25 \\
Meaning & & Adverb & 0 & - \\
\cline { 2 - 5 } & & Conjunction & 1 & 5 \\
& \multirow{2}{*}{ Antonym } & Noun & 8 & 40 \\
& & Pronoun & 1 & 5 \\
\hline & Verb & 5 & 25 \\
\hline
\end{tabular}

\section{Population and Sample}

The population of this research was the second grade of SMP HKBP PAJAK BARU BELAWAN which is located at Jl. Terubuk No 17, Belawan Bahagia, Medan Kota Belawan. There was three classes. Each class has 20 students. The sample of this research was the second grade students of eighth grade of SMP HKBP PAJAK BARU BELAWAN. The students was taken as the sample is about 20 students from the total number of population, and then they were divided into two groups : the experimental group and control group. 


\section{Pre Test}

The pre-test were given to both (experimental group and control group) before the treatment. The pre-test was conducted to find out the homogeneity of the sample and the mean score of each group. In this case, the teacher given the test to students. The kinds of test is a narrative text. The teacher were given to the students a text and question based on the text and the teacher ask the students to read the text and answer the question.

\section{Treatment}

After the pre-test, the treatment was conducted only in experimental group. The students in the experimental group, was taught by applying Reading Short Story technique, while the control group was taught by applying conventional strategy. Post Test

After the teaching presentation, both of experimental and control group, the post-test was given to the both group after treatment was completed. The test items in the post-test was exactly same as those in the pre-test. This post- test was used to find out the mean score of exxperimental group and control group. The post-test was used to know the effect of using Reading Short Story technique.

\section{Scoring the Test}

To score the test, the writer was used score ranging from 0 to 100 by counting the counting the correct answer and applying the formula:

$$
S={ }_{N}^{R} X 100 \%
$$

Where: $\mathrm{S}=$ The Score

$\mathrm{R}=$ The Right Answer

$\mathrm{N}=$ Number of Test Items

\section{Technique of Data Analysis}

To analyze the data, the writer was used score of post-test of the experimental and control groups. These scores was analyzed by using statistical analysis. The data was analyzed by using T-test (pair sample t-test).

To know the effect of result of this research, the test was calculated using-test formula as follow that developed by Arikunto:

$$
\mathrm{t}=\frac{\mathrm{M}_{\mathrm{X}-\mathrm{M}_{\mathrm{Y}}}}{\sqrt{\left[\frac{\mathrm{dx}^{2}+\mathrm{dy}^{2}}{\left(\mathrm{~N}_{\mathrm{X}}+\mathrm{N}_{\mathrm{y}}\right)-2}\right]\left[\frac{1}{N_{\mathrm{X}}}+\frac{1}{\mathrm{~N}_{Y}}\right]}}
$$

Where:

$\mathrm{M}_{\mathrm{x}} \quad=$ the mean of experimental group

$\mathrm{M}_{\mathrm{y}} \quad=$ the mean of control group

$\mathrm{dx}^{2}=$ standard deviation of experimental group

$\mathrm{dy}^{2} \quad=$ standard deviation of control group

$\mathrm{N}_{\mathrm{x}} \quad=$ the total number of experimental group

$\mathrm{N}_{\mathrm{y}} \quad=$ the total number of control group 
The T-table was employed to see whether or not there is significant different between the mean score in both experimental and control groups.

\section{Validity of the Test}

Arikunto (2010:168) state the validity is a measurement with shows the level of the instruments validity. An instrument can be said valid if it caan measure what is supposed to be measured. There were four types of validity, namely, content validity, construct validity, concurrent validity and predictif validity . this research was conducted with content validity. Content validity considers whether a test will the necessary and appropriate content to measure what is supposed to. So in this case the validity of the test is to know whether the test really measures the students' vocabulary mastery or not.

Table 3. The Table of the Test Specification

\begin{tabular}{cccc}
\hline Content & Test item & Kinds of Test & Score \\
\hline Synonym & 10 & Multiple choice & 50 \\
Antonym & 10 & Multiple choice & 50 \\
\hline Total & 20 & & 100 \\
\hline
\end{tabular}

Based on the content validity of synonym and antonym above, the writer was given 1 text which is consist of 20 questions. The detail was explained by in this following table:

\begin{tabular}{lllcc}
\hline Content & $\begin{array}{c}\text { Kinds of } \\
\text { Word } \\
\text { Meaning }\end{array}$ & Content & $\begin{array}{c}\text { Test } \\
\text { Item }\end{array}$ & Question Number \\
\hline Word & Synonym & Adjective & 5 & $1,2,3,4,6$ \\
& & Adverb & 0 & - \\
& & Conjunction & 1 & 15 \\
\cline { 2 - 5 } & Antonym & Noun & 8 & $7,9,12,14,16,17,18,19$ \\
& & Pronoun & 1 & 20 \\
& & Verb & 5 & $5,8,10,11,13$ \\
\hline \multicolumn{2}{c}{ Total } & & $\mathbf{2 0}$ & \\
\hline
\end{tabular}

\section{Reliability of the Test}

Arikunto (2010:178) say that reliability shows as instrument that can be trusted use as a tool of collecting the data because it has already a good enough. A good instrument is tendencies to lead the respondent in choosing certain answer. If the data appropriate to the fact, the result will be the same although it is exercises many times. It means that reliability refers to the consistency of the measurement.

In order to find out whether the test reliable or not, the writer used the formula 20 of Kuder Richards in Arikunto (,2007:100) as following :

$\mathrm{r} 11=\left(\frac{n}{n-1}\right)\left(\frac{S^{2}-\sum \mathrm{pq}}{S^{2}}\right)$

Where :

$\mathrm{R} \quad$ : Reliability of Instrument.

n : The number of items in the test.

M : The mean of the test score. 
$\mathrm{T} \quad$ : Total of variance

S : Standard deviation of the test score.

The calculation shows that the reliability of instrument of the test was $\mathrm{R}=$

0.0-0.20 : The reliability is very low

0.20-0.40 : The reliability is low

0.40-0.60 : The reliability is fair

0.60-0.80 : The reliability is high

0.80-1.0 : The reliability is very high

\section{Data Analysis}

This study was conducted by using experimental Research. In this research, the sample was divided into two groups, the experimental group and control group and the subject of this study are eight grade students of SMP HKBP PAJAK BARU BELAWAN. Class VIII-A and VIII-B used as the sample, Class VIII-A as the experimental group, and class VIII-B as the control group. The control group was taught by using conventional strategy while the experimental group was a group taught by using Reading Short Story. Group were given the pre test and post test to find out the differences of them and only the experimental group accepted treatment.

The data in this research were the score of the students both of experimental group and control group (pre test and post test). Before giving treatment, the research conducted pre test to both groups. The test was 20 items of multiple choices. The treatment was conducted in experimental group. In the control group, the teacher applied conventional strategy. After the treatment the research gave post test to both of group.

After the test administered to both of groups, control and experimental by using the research (pre test and post test). The writer collected the answer sheet of both group. After that, their answer were scored, and then their score tabulated. The writer taught the experimental group by using treatment ( Reading Short Story). Its function is to see whether Reading Short Story has an effect in students' vocabulary mastery or not. The scores of students in experimental group are shown in the following table:

Table 4.The Students' Score In Pre -Test of Experimental Group

\begin{tabular}{|c|c|c|c|c|c|c|c|c|}
\hline \multirow[t]{2}{*}{ No } & \multirow{2}{*}{$\begin{array}{l}\text { Students' } \\
\text { Initial Name }\end{array}$} & \multicolumn{2}{|c|}{ Synonym } & \multicolumn{4}{|c|}{ Antonym } & \multirow{2}{*}{$\begin{array}{l}\text { Total } \\
\text { Score }\end{array}$} \\
\hline & & Adj & Adv & Conj & $\mathbf{N}$ & $\mathbf{P}$ & $\mathbf{V}$ & \\
\hline 1 & SAS & 25 & - & 10 & 20 & - & 5 & 60 \\
\hline 2 & IPN & 30 & - & 10 & 15 & 5 & - & 60 \\
\hline 3 & KES & 30 & 5 & - & 15 & - & - & 50 \\
\hline 4 & $\mathrm{TP}$ & 30 & 5 & 5 & 15 & 5 & 5 & 65 \\
\hline 5 & TSP & 20 & - & 10 & 25 & - & 5 & 60 \\
\hline 6 & DSS & 30 & 5 & 5 & 15 & 5 & 5 & 65 \\
\hline 7 & MMS & 20 & 5 & 5 & 20 & - & - & 50 \\
\hline 8 & JSS & 25 & - & 10 & 25 & - & - & 60 \\
\hline 9 & MS & 5 & - & 15 & 25 & - & - & 65 \\
\hline 10 & JFS & 30 & - & 15 & 25 & - & - & 70 \\
\hline
\end{tabular}

Published by English Lecturers and Teachers Association (ELTA)

Copyright (C) 2021, authors 


\begin{tabular}{lcccccccc}
11 & JCS & 25 & - & 10 & 25 & 5 & - & 65 \\
12 & RSN & 20 & - & 10 & 15 & 5 & - & 50 \\
13 & FCL & 20 & - & 15 & 15 & 5 & 5 & 60 \\
14 & BYN & 30 & - & 15 & 20 & - & 5 & 70 \\
15 & SAA & 30 & - & 10 & 20 & - & - & 60 \\
16 & PLS & 35 & - & 10 & 10 & 5 & 5 & 65 \\
17 & YS & 15 & - & 15 & 20 & 5 & - & 55 \\
18 & DPT & 30 & - & 5 & 15 & - & 5 & 55 \\
19 & MDP & 25 & - & 15 & 20 & 5 & - & 65 \\
20 & JHS & 30 & - & 10 & 10 & - & - & 50 \\
\hline & TOTAL & & & & & & & $\mathbf{1 2 0 0}$ \\
\cline { 2 - 7 } & MEAN & & & & & & & \\
\hline
\end{tabular}

Table 4.2 The Students' Score in Post Test of Experimental Group

\begin{tabular}{|c|c|c|c|c|c|c|c|c|}
\hline \multirow[t]{2}{*}{ No } & \multirow{2}{*}{$\begin{array}{c}\text { Students' } \\
\text { Initial Name }\end{array}$} & \multicolumn{3}{|c|}{ Synonym } & \multicolumn{3}{|c|}{ Antonym } & \multirow{2}{*}{$\begin{array}{l}\text { Total } \\
\text { Score }\end{array}$} \\
\hline & & Adj & Adv & Conj & $\mathbf{N}$ & $\mathbf{P}$ & $\mathbf{V}$ & \\
\hline 1 & SAS & 30 & - & 15 & 20 & 5 & - & 70 \\
\hline 2 & IPN & 40 & - & 15 & 5 & 5 & 5 & 70 \\
\hline 3 & KES & 30 & - & 15 & 25 & 5 & 5 & 80 \\
\hline 4 & $\mathrm{TP}$ & 35 & - & 15 & 15 & 5 & 5 & 75 \\
\hline 5 & TSP & 35 & - & 15 & 25 & 5 & - & 80 \\
\hline 6 & DSS & 25 & - & 15 & 25 & 5 & 5 & 80 \\
\hline 7 & JSS & 25 & - & 15 & 20 & 5 & 5 & 75 \\
\hline 8 & MMS & 35 & - & 25 & 20 & 5 & - & 75 \\
\hline 9 & MS & 35 & - & 15 & 25 & 5 & - & 80 \\
\hline 10 & JFS & 30 & - & 15 & 25 & 5 & 5 & 85 \\
\hline 11 & JCS & 30 & - & 15 & 25 & 5 & - & 75 \\
\hline 12 & RRN & 25 & - & 15 & 10 & 5 & 5 & 60 \\
\hline 13 & FCL & 35 & - & 15 & 20 & 5 & - & 75 \\
\hline 14 & BYN & 30 & - & 15 & 25 & 5 & 5 & 80 \\
\hline 15 & SAA & 25 & - & 20 & 25 & 5 & - & 70 \\
\hline 16 & PLS & 30 & - & 15 & 20 & 5 & - & 70 \\
\hline 17 & YS & 35 & - & 15 & 20 & 5 & 5 & 85 \\
\hline 18 & DPT & 35 & - & 10 & 15 & 5 & 5 & 70 \\
\hline 19 & MDP & 25 & - & 15 & 25 & 5 & 5 & 75 \\
\hline 20 & JHS & 40 & - & 15 & 20 & 5 & - & 75 \\
\hline
\end{tabular}

Published by English Lecturers and Teachers Association (ELTA)

Copyright (C) 2021, authors 
From the table above, it is shown that in Experimental Group the total group score in pre-test is 1200 and the mean score is 60 . The lowest score for pre-test is 50 and the highest is 65 . While the post- test, the total score in 1505 and the mean score is 75,25 . The lowest score is 70 and the highest is 85 .

Then the research also taught the control group without a treatment (Reading Short Story). The scores of students in control group are shown in the following table:

Table 5.The Students' Score in Pre-Test of Control Group

\begin{tabular}{|c|c|c|c|c|c|c|c|c|}
\hline \multirow[t]{2}{*}{ No } & \multirow{2}{*}{$\begin{array}{c}\text { Students' } \\
\text { Initial Name }\end{array}$} & \multicolumn{3}{|c|}{ Synonym } & \multicolumn{3}{|c|}{ Antonym } & \multirow{2}{*}{$\begin{array}{l}\text { Total } \\
\text { Score }\end{array}$} \\
\hline & & Adj & Adv & Conj & $\mathbf{N}$ & $\mathbf{P}$ & $\mathbf{V}$ & \\
\hline 1 & AP & 20 & - & 10 & 10 & 5 & 5 & 40 \\
\hline 2 & AS & 25 & - & 20 & 20 & - & 5 & 50 \\
\hline 3 & CJP & 30 & - & 10 & 10 & 5 & - & 50 \\
\hline 4 & $\mathrm{CN}$ & 25 & - & 10 & 10 & 5 & 0 & 45 \\
\hline 5 & DT & 30 & - & 15 & 15 & - & 5 & 50 \\
\hline 6 & DR & 30 & - & 5 & 5 & - & - & 40 \\
\hline 7 & FS & 15 & - & 25 & 25 & 5 & - & 50 \\
\hline 8 & FM & 10 & - & 30 & 30 & - & - & 50 \\
\hline 9 & GN & 20 & - & 15 & 20 & - & - & 55 \\
\hline 10 & JS & 10 & - & 15 & 10 & - & - & 35 \\
\hline 11 & AS & 25 & - & 5 & 5 & 5 & - & 40 \\
\hline 12 & NS & 20 & - & 15 & 15 & 5 & 5 & 50 \\
\hline 13 & MR & 25 & - & 25 & 25 & - & 5 & 55 \\
\hline 14 & $\mathrm{RS}$ & 25 & - & 25 & 25 & - & 5 & 50 \\
\hline 15 & $\mathrm{RS}$ & 30 & - & 5 & 5 & - & - & 35 \\
\hline 16 & RG & 15 & - & 10 & 10 & 5 & - & 40 \\
\hline 17 & RA & 20 & - & 5 & 5 & 5 & 5 & 40 \\
\hline 18 & VN & 15 & - & - & 10 & 5 & - & 30 \\
\hline 19 & YR & 15 & - & - & 10 & 5 & - & 30 \\
\hline \multirow[t]{3}{*}{20} & NS & 15 & - & 5 & 15 & 5 & 5 & 45 \\
\hline & TOTAL & & & & & & & 880 \\
\hline & MEAN & & & & & & & 44 \\
\hline
\end{tabular}

Table 6. The Students' Score in Post-Test of Control Group

\begin{tabular}{ccccc}
\hline No & $\begin{array}{c}\text { Students' } \\
\text { Initial Name }\end{array}$ & Synonym & Antonym & $\begin{array}{c}\text { Total } \\
\text { Score }\end{array}$ \\
\cline { 3 - 4 }
\end{tabular}




\begin{tabular}{lcccccccc}
\cline { 3 - 8 } & & Adj & Adv & Conj & N & P & V & \\
\hline 1 & AP & 35 & - & 15 & 20 & 5 & - & 75 \\
2 & AS & 45 & - & 10 & 10 & 5 & 5 & 75 \\
3 & CJP & 30 & - & 15 & 20 & 5 & 5 & 75 \\
4 & CN & 40 & - & 5 & 20 & 5 & 5 & 75 \\
5 & DT & 35 & - & 15 & 25 & 5 & - & 80 \\
6 & DR & 40 & - & 15 & 20 & 5 & - & 80 \\
7 & FS & 40 & - & 10 & 15 & 5 & 5 & 75 \\
8 & FM & 35 & - & 15 & 20 & 5 & 5 & 80 \\
9 & GN & 30 & - & 15 & 20 & 5 & 5 & 75 \\
10 & JS & 35 & - & 10 & 10 & 5 & - & 60 \\
11 & AS & 35 & - & 15 & 15 & 5 & - & 70 \\
12 & NS & 35 & - & 15 & 10 & 5 & 5 & 70 \\
13 & MR & 35 & - & 15 & 10 & 5 & 5 & 70 \\
14 & RS & 30 & - & 15 & 25 & 5 & - & 75 \\
15 & RS & 25 & - & 15 & 15 & 5 & - & 60 \\
16 & RG & 40 & - & 10 & 15 & 5 & - & 70 \\
17 & RA & 30 & - & 15 & 15 & 5 & - & 65 \\
18 & VN & 35 & - & 15 & 20 & 5 & - & 75 \\
19 & YR & 30 & - & 15 & 10 & 5 & - & 65 \\
20 & NS & 35 & - & 15 & 20 & 5 & - & 75 \\
\hline & TOTAL & & & & & & & $\mathbf{1 4 5 5}$ \\
\hline & MEAN & & & & & & & $\mathbf{7 2 , 7 5}$ \\
\hline
\end{tabular}

The data shows that there is improve of students' vocabulary mastery after they were taught by using reading short story technique.

From the table above, it is shown that in Control Group score in pre test 880 and the mean score is 44. The lowest score for pre test is 30 and the highest is 55 . While the post test, the total score is 1455 and the mean score is 68,99 . The lowest score is 60 and the highest is 80 .

\section{The Validity as the Test}

An instrument can be said valid if it can measure what is support to be measured and test can be said having a good content validity if every item in the test represent the content or material that is supposed to be mastered proportionally. In vocabulary test, content validity refers to extent to which a test measure a repetitive sample of the subject matter or the behavioral change under consideration. In this research, the content validity should not be counted because the instrument that is taken from the collection vocabulary and spelling test question test. The content validity of each item has already measure and has been valid.

\section{The Reliability of the Test}

This research requires a test of reliability, to find the quality of consistency of the test. The test called reliable when there is consistency whenever it is used to measure because the reliability of the test is 
one of characteristics of a good test. It means the same result when it is used to test the different people in different time.

To obtain the reliability of the test, the research used Kuder Richardson Formula 20 (Arikunto, 2007:100) as follows:

$$
\mathrm{r} 11=\left(\frac{\square}{\square-1}\right)\left(\frac{\square^{2}-\sum \mathrm{pq}}{\square^{2}}\right)
$$

The data reliability test is taken from the following table

From the data of reliability of the test, the data was founded as follows:

$\sum \square=189 \quad \sum \square^{2}=1975$

$\mathrm{N}=20$

Before calculating the reliability, firstly the writer calculates $S^{2}$ with formula

$\mathrm{S}^{2}=\frac{\sum \square^{2}-\sum(\square)^{2}}{\mathrm{n}}$

$\mathrm{S}^{2}=\frac{\sum \square^{2}-\sum \frac{(189) 2}{20}}{20}$

$\mathrm{S}^{2}=\frac{\sum 1975-\frac{35721}{20}}{20}$

$S^{2}=9,4475$

So the calculation of the reliability in analyzing the test was applied by using this following technique:

$\mathrm{r} 11=\left(\frac{\square}{\square-1}\right)\left(\mathrm{S}^{2-\frac{\sum \square \square}{\mathrm{S}^{2}}}\right)$

r11 $=\left(\frac{20}{20-1}\right)\left(\frac{9,4475-4,1675)}{9,4475}\right)$

$\mathrm{r} 11=\left(\frac{20}{19}\right)\left(\frac{5,28}{9,4475}\right)$

$\mathrm{r} 11=(1,0526) .(0,5589)$

r11 $=0,5883$.

By having calculation, it was found that the reliability of the test is 0,5883 deal with the level of reliability test, this test is significant reliable because it is correlated with the level of the reliability of the test which categorized as the following:

0.00-0.20 : The reliability is very low

0.21-00.40 : The reliability is low

0.41-00.60 : The reliability is fair

0.61-00.80 : The reliability is high

0.81 above : The reliability is very high

From the calculation about the result of the reliability is 0,5883 , it can be concluded that the reliability of the test is fair.

\section{Analyzing the Data by Using t-test Formula.}

T-test Formula is used to find the significance of the difference between the mean of experimental Group and control Group in pre test and post test. The result of formula calculating is used to find out whether the using Reading Short Story has a significant effect on students' vocabulary mastery. The result our pre test and post test by the students in experimental group can be shown by the follwing table:

Table 7. Calculation of Experimental Group

\begin{tabular}{llllll}
\hline No & Students' Name & Pre Test & Post Test & Deviation & Squared \\
\hline
\end{tabular}

Published by English Lecturers and Teachers Association (ELTA)

Copyright (C) 2021, authors 


\begin{tabular}{cccccc}
\hline & & & & $\left(\mathbf{d}=\mathbf{X}_{\mathbf{2}} \mathbf{X}_{\mathbf{1}}\right)$ & $\begin{array}{c}\text { Deviation } \\
\left(\mathbf{d}^{\mathbf{2}}\right)\end{array}$ \\
\hline 1 & SAS & 60 & 70 & 10 & 100 \\
2 & IPN & 60 & 70 & 10 & 100 \\
3 & KES & 50 & 80 & 30 & 900 \\
4 & TP & 65 & 75 & 10 & 100 \\
5 & TSP & 60 & 75 & 15 & 225 \\
6 & DSS & 65 & 80 & 15 & 225 \\
7 & MMS & 50 & 75 & 25 & 625 \\
8 & JSS & 60 & 75 & 15 & 225 \\
9 & MS & 65 & 80 & 15 & 225 \\
10 & JFS & 70 & 85 & 15 & 225 \\
11 & JCS & 65 & 75 & 10 & 100 \\
12 & RSN & 50 & 60 & 10 & 100 \\
13 & FCL & 60 & 75 & 15 & 225 \\
14 & BYN & 70 & 80 & 10 & 100 \\
15 & SAA & 60 & 70 & 10 & 100 \\
16 & PLS & 65 & 80 & 15 & 225 \\
17 & YS & 55 & 80 & 25 & 625 \\
18 & DPT & 55 & 70 & 15 & 225 \\
19 & MDP & 65 & 75 & 10 & 100 \\
20 & JHS & 50 & 75 & 25 & 625 \\
\hline & TOTAL & $\mathbf{1 2 0 0}$ & $\mathbf{1 5 0 5}$ & $\mathbf{3 0 5}$ & $\mathbf{5 3 7 5}$ \\
\hline & MEAN & $\mathbf{6 0}$ & $\mathbf{7 5 , 2 5}$ & $\mathbf{1 5 , 2 5}$ & \\
\hline & & & & \\
\hline
\end{tabular}

From the table above, the mean score of experimental group is calculated as the following: $\mathrm{Mx}=$ $\frac{\sum \mathrm{d}}{\mathrm{N}}$

$$
\begin{aligned}
& M x=\frac{1505}{20} \\
& M x=75,25
\end{aligned}
$$

The deviation square of Experimental group was calculated as follows:

$$
\begin{aligned}
& \mathrm{dx}^{2}=\left(\sum_{\square} 2\right)-\frac{\left(\sum \square\right) 2}{\square} \\
& \mathrm{dx}^{2}=(\mathbf{5 3 7 5})-\frac{(305) 2}{20} \\
& \mathrm{dx}^{2}=(5375)-\frac{93025}{20} \\
& \mathrm{dx}^{2}=5375-4651,2 \\
& \mathrm{dx}^{2}=723,75
\end{aligned}
$$

From the table above, the mean score of experimental group is calculated as the following: $M x=\frac{\sum \mathrm{d}}{\mathrm{N}}$

$$
\mathrm{Mx}=\frac{1505}{20}
$$




$$
\mathrm{Mx}=75,25
$$

The deviation square of Experimental group was calculated as follows:

$$
\begin{aligned}
& \mathrm{dx}^{2}=\left(\sum_{\mathrm{x}} 2\right)-\frac{\left(\sum \mathrm{x}\right) 2}{\mathrm{~N}} \\
& \mathrm{dx}^{2}=(\mathbf{5 3 7 5})-\frac{(305) 2}{20} \\
& \mathrm{dx}^{2}=(5375)-\frac{\square}{\square} \\
& \mathrm{dx}^{2}=5375-4651,2 \\
& \mathrm{dx}^{2}=723,75
\end{aligned}
$$

The following table is the score of pre test and post test of Control Group

Table 8. The calculation of control group

\begin{tabular}{cccccc}
\hline No. & Students' Name & Pre test & Post test & $\begin{array}{c}\text { Deviation } \\
\mathbf{d}= \\
\left(\mathbf{Y}_{\mathbf{1}} \mathbf{Y}_{\mathbf{2}}\right)\end{array}$ & $\begin{array}{c}\text { Squared } \\
\text { Deviation } \\
\left(\mathbf{d}^{\mathbf{2}}\right)\end{array}$ \\
\hline 1 & & & 25 & 625 \\
2 & AP & 50 & 75 & 15 & 225 \\
3 & AS & 60 & 75 & 5 & 25 \\
4 & CJP & 70 & 75 & 5 & 25 \\
5 & CN & 70 & 75 & 10 & 100 \\
6 & DT & 70 & 80 & 15 & 225 \\
7 & DR & 65 & 80 & 20 & 400 \\
8 & FS & 55 & 75 & 10 & 100 \\
9 & FM & 70 & 80 & 10 & 100 \\
10 & GN & 65 & 75 & 10 & 100 \\
11 & JS & 65 & 75 & 10 & 100 \\
12 & AS & 60 & 70 & 5 & 25 \\
13 & NS & 65 & 70 & 10 & 100 \\
14 & MR & 65 & 75 & 10 & 100 \\
15 & RS & 60 & 70 & 5 & 25 \\
16 & RS & 55 & 60 & 10 & 100 \\
17 & RG & 60 & 70 & 10 & 100 \\
18 & RA & 55 & 65 & 15 & 225 \\
19 & VN & 60 & 75 & 10 & 100 \\
20 & YR & 50 & 60 & 15 & 225 \\
\hline & NS & 60 & 75 & $\mathbf{2 2 5}$ & $\mathbf{3 0 2 5}$ \\
\hline & TOTAL & $\mathbf{8 8 0}$ & $\mathbf{1 4 5 5}$ & $\mathbf{1 1 , 2 5}$ & \\
\hline
\end{tabular}

Fom the table above, the mean score of Control group is calculated as the following: $\mathrm{Mx}=\frac{\sum \mathrm{d}}{\mathrm{N}}$

$$
\begin{aligned}
& \text { My }=\frac{\square \square \square}{\square \square} \\
& \text { My }=72,75
\end{aligned}
$$

Published by English Lecturers and Teachers Association (ELTA)

Copyright (C) 2021, authors 
The deviation square of Experiment group was calculated as follows:

$$
\begin{aligned}
& \mathrm{dy}^{2}=\left(\sum_{\mathrm{y}} 2\right)-\frac{\left(\sum \mathrm{y}\right) 2}{\mathrm{~N}} \\
& \mathrm{dy}^{2}=(\mathbf{3 0 2 5})-\frac{(\square \square) \square}{\square \square} \\
& \mathrm{dy}^{2}=(3025)-\frac{\square \square \square \square}{\square \square} \\
& \mathrm{dy}^{2}=3025-2531,25 \\
& \mathrm{dy}^{2}=493,75
\end{aligned}
$$

To find out whether that applying Reading Short Story affect the students' vocabulary mastery significantly, t-test can be used as formula. The t- test is calculated as the following:

$$
t=\frac{M_{X-} M_{Y}}{\sqrt{\left[\frac{d x^{2}+d y^{2}}{\left(N_{X}+N_{y}\right)-2}\right]\left[\frac{1}{N_{X}}+\frac{1}{N_{Y}}\right]}}
$$
$\mathrm{Mx}=75,25$
$\mathrm{dy}^{2}=493,75$
$\mathrm{My}=72,75$
$\mathrm{Nx}=20$
$\mathrm{dx}^{2}=723,75$
$\mathrm{Ny}=20$

The result of t-test calculated as the following:

$\mathrm{t}=\frac{75,25-72,75}{\sqrt{\left[\frac{723,75+493,75}{20+20-2}\right]\left[\frac{1}{20}+\frac{1}{20}\right]}}$

$\mathrm{t}=\frac{2,5}{\sqrt{\left[\frac{121,75}{38}\right]\left[\frac{2}{20}\right]}}$

$\mathrm{t}=\frac{2,5}{\sqrt{(32,04)[0,01]}}$

$\mathrm{t}=\frac{2,5}{\sqrt{0,32}}$

$\mathrm{t}=\frac{2,5}{0,56}$

$\mathrm{t}=4,46$

After adopting the data into t-test formula, it is obtained that t-observed is 4,46 . The t-observe is bigger than t-table $(4,46>1,686: p=0,05)$. It means that the alternative hypothesis said that "The Effect of Reading Short Story in Students' Vocabulary Mastery" is accepted and null hypothesis (Ho) is rejected prove this hypothesis, the writer used critical values of students' distribution $(t)$ at the level of significance: 0,05 , with $\mathrm{N}$ table $=40$

$$
\begin{aligned}
& (\mathrm{df})=\mathrm{Nx}+\mathrm{Ny}-2 \\
& (\mathrm{df})=20+20-2 \\
& (\mathrm{df})=38
\end{aligned}
$$

\section{Testing Hypothesis}

Testing the hypothesis is done to find out whether the hypothesis is accepted or rejected. The main principles of testing the hypothesis are:

If $\mathrm{t}$-observed $>\mathrm{t}$-table, Ha will be accepted and Ho will be rejected

If $\mathrm{t}$-observed $<\mathrm{t}$-table, Ho will be accepted and $\mathrm{Ha}$ will be rejected

Published by English Lecturers and Teachers Association (ELTA)

Copyright (C) 2021, authors 
Based on the calculation of the test in this research, it is found that t-observed $>\mathrm{t}$-table $(4,46>$ 1,686 ) with degree of freedom (df) 38 at the level of significance os 0,05 . Therefore, it can be conclude that the alternative

hypothesis (Ha) is accepted and the null hypothesis (Ho) is rejected. The conclusion means that using of Reading Short Story giving significant effect in students' vocabulary mastery.

\section{Research Finding}

Based on the calculation in this research shows that mean score of the experimental group $(75,25)$ higher that control group $(72,75)$. The difference is tested by using t-test formula. The result of the calculation shows that t-observed value $(4,46)$ is higher than t-table value $(1,686)$. It can be concluded that there is a significant effect of Reading Short Story in students' vocabulary mastery. In other words, alternative hypothesis (Ha) is accepted and null hypothesis (Ho) is rejected.

\section{Discussion}

Before answering the test, the students have to predict what they are going to choose as the correct answer. But in fact, in pre-test the students answered the test based on their understanding and the result was bar from expectation. It is happen because the students do not understand yet about synonym and antonym.

As this research was aimed to answer the question about the implementation of short story technique whether it can enrich the students' English vocabulary at Class VIII SMP HKBP PAJAK BARU BELAWAN or not, the writer tested the null hypothesis (Ho) which stated that the use of short story cannot enrich the students' English vocabulary at Class VIII SMP HKBP PAJAK BARU BELAWAN and research hypothesis $(\mathrm{Ha})$ that is the use of short story can enrich the students' English vocabulary at SMP HKBP PAJAK BARU BELAWAN.

Thus, the writer can conclude that the use of short story can enrich the students' English vocabulary at Class VIII SMP HKBP PAJAK BARU BELAWAN During the teaching and learning process, students are obedient with the writer. It is understandable because the students at Class Darul VIII SMP HKBP PAJAK BARU BELAWAN characterized with good and polite attitudes towards their teachers and other people.

Thus the writer do not find any serious obstacles related to students' behavior. The class is also condusive because it only has 20 students, thus it is comfortable for both students and the writer. The problem found in the class is related to their low mastery of English vocabulary. Before the short story technique was applied in Class VIII A, the students' English vocabulary is limited. This also happen because the students do not practice the vocabulary taught by their teachers in everyday life, thus the new and important vocabularies were forgotten. This is worsened by the fact that the reading texts used in teaching some vocabularis are not containing interesting topics, resulted many students are not enthusiastic in reading the texts or in gueesing the meaning of the new English vocabularies they found in the texts. However, after the writer introduced short story technique, the students can remember and know the meaning of the vocabularies from the texts. Consequently their postest of vocabulary mastery score was increased.

There are some intriguing findings in students' pretest and posttest. In pretest, some students provide the meaning of word 'morning' as 'selamat pagi'. Actually, the meaning of word 'morning' as 'pagi', but they thought it was 'selamat pagi' because they usually hear or use it in greetings. Similar condition also happen for the word 'afternoon'. Then, one student translate the word'help' as 'hand phone'. In post test, some students provide the meaning of word 'place' as 'mohon' which is the meaning of word 'please'. The students gave wrong translation of the word 'place' because the pronunciation of word 'place' and 'please' is almost the same. This also occured in word 'mocking' which means 'mengejek', but some students translate it to 'merokok' which is the translation of word 'smoking'. In addition, some students provide the meaning of word 'rich' as 'nasi' which is the meaning of word 'rice'. The students gave wrong translation of the word 'place' because the words 'rich' and 'rice' has almost the same form of writing. Then, some students translate the word 'dawn' as 'duduk'. This is because the students usually hear the word 'dawn' pronounce

Published by English Lecturers and Teachers Association (ELTA)

Copyright (C) 2021, authors 
similarly to word 'down', and the students usually hear the word 'down' in phrase 'sit down' every time they greet teachers in their classroom.

All of these findings indicate that there is a crucial need to teach correct pronunciation of English vocabulary for students in applying reading short story, unless they will be trapped in defining the vocabularies they found in the short story incorrectly. For the students' perception, it was revealed that they are happy studying vocabulary by using reading short story. Most of them say that they are happy studying vocabulary by using reading short story because they can get a lot of new vocabularies. They say that reading short story improve their ability in mastering vocabulary.Then most of the students say that reading short story benefits them by providing new insight. Most of the students say that they practice the vocabulary in everyday life sometimes, therefore their vocabulary mastery is not much increased.

Furthermore, most of the students say that there are many difficult vocabularies in reading short story. This condition is understandable because the students do not often practice and use the new vocabularies in their everday life; they do not frequently apply the vocabulary in their classroom and outside their classroom. Overall, the students give positive perception towards reading short story. They say that reading short story increase their vocabulary mastery.

\section{Synonym}

The students vocabulary mastery in synonym is lack. It is happen because they do not understand what modifier should they use to modify the noun of synonym, by the score, the writer gave specia treatment to the students did not care with their work and did not organize the classroom well. But not all the students understand the topic. After teaching the students by using Reading Short Story. The writer did a test again. The result was better than before, but only a few students get good score.

\section{Antonym}

The students' mastery in antonym is lack as the synonym. It is because the students do not understand how to easier understand the antonym, they think that antonym has a similar meaning. Meanwhile the antonym is opposite meaning. But the mass, and the modifier that used in Synonym is different with antonym. In synonym is similar meaning and antonym is opposite meaning.

\section{Conclusion}

After doing the research, it is found that Reading Short Story significantly affect the students' vocabulary test. In teaching vocabulary by using Reading Short Story shows the better result than of not using Reading Short Story (Experimental Group) get the higher scores than the students who are taught by using Reading Short Story (control group). There is significant difference of mean score got both of experimental group (75.25) and the control group (72,75). T-observe $>\mathrm{T}-$ table $(\mathrm{P}=0,05) \mathrm{df}(38)$, or 4,46 $>1,686(\mathrm{P}=0,05)$. It means that alternative hypothesis $(\mathrm{Ha})$ is accepted and null hypothesis $(\mathrm{Ho})$ is rejected. Thus it can be conclude that by using Reading Short Story affects the students' vocabulary mastery.

\section{REFERENCES}

Aeberson and Field. (1997). Language and teaching English: A course forteacher. UK: Oxford University Press.

Al Alami, S. (2016). The power of short stories, novellas, an novels in today'sworld. International Journal of Language and Literature, 4(1), 21-35.

Al-Dersi, Z.E. (2013). The use of short stories for developing vocabulary of EFLlearners. International Journal of English Language \& Translation Studies.1(1), 72-86. 
Arikunto, S. (2006). Prosedur penelitian: Suatu pendekatan praktik [Researchprocedure; A practical approach] (Fifth Edition). Jakarta: Rineka Cipta.

Coconi, A. (2017). Three major differences and similarities between the shortstory and novel. Accessed from.https://penandthepad.com/three-betweenshort-story-novel-8700799.html. on January 5, 2018.

Collie, J. And Slater, S. (1991). Cambridge skills for fluency speaking 2.Cambridge: Cambridge University Press.

Das, S. (2018). Ramsh K. Srivastava's Road Not Taken and ther Stories.International Journal on Multicultural Literature (IJML). 8(1), 141-144.

Diana, F. (2011). Increasing Students' Vocabulary through Islamic Short Stories.Banda Aceh: IAIN ArRaniry.

Joseph (2015). Pros and Cons of Short Stories. Accessed fromblogs.isb.bj.edu.cn/19josephz/2015/09/25/pros-and-cons-of-short-stories/on January 5, 2018.

Lepaludier, L. (2011). Threaticality in the short story: Staging the word? Journal of the Short Story in English, 51, 1-10.

Mofareh, A. (2015). The importance of vocabulary in language learning and howto be taught. International Journal of Teaching and Education, 3(3), 21-34.

Muijs, D. (2004). Doing Quantitative Research in Education with SPSS. London:Sage Production.

Nunan, D. (1991). Task Based Language Teaching. Hall International (UK) Ltd.

Pardede, P. (2011). Using short stories to teach language skills. parlindungan pardede.wordpress.com/articles/language-teaching/using-short-stories-to-teach-language-skills/ on November 15, 2017.

Richard, J.C. and Rodgers, T.S. (2001). Approaches and Methods in Language Teaching. Cambridge: Cambridge University Press.

Shilpa, B.S.L. (2015). Narratives and types of narrators illustrated using O'Henry'sshortstories. International Journal of Multidisciplinary Consortium, 2(2), 1-5.

Sudijono, A. (2012) Pengantar evsluasi pendidikan. Jakarta: Raja Grafindo Persada.

Ur, P. (1998). A course in language teaching, practice and theory. Cambridge:Cambridge University Press.

Webb, S. (2005). Receptive and productive vocabulary learning: The effects of reading and writing on word knowledge. Studies in Second Language Acquisition, 27(1), 33-52.

Webb, S. (2009). The effects of pre-learning vocabulary on reading comprehension and writing. Canadian Modern Language Review, 65(3),441-470.

Published by English Lecturers and Teachers Association (ELTA)

Copyright $\mathbb{C}$ 2021, authors 